CONF-950908- - 11

procoedings of the 2nd Intemational Conference on Heat-Resistant Materials, Gattinburg. Tennessee, 11-14 September, 1995

\title{
Reaction Synthesis of Heat-Resistant Materials
}

\author{
S. C. Deevi and V. K. Sikka \\ Oak Ridge National Laboratory \\ OakRidge, Tennessee
}

\begin{abstract}
Exothermicity associated with the synthesis of aluminides can be utilized to obtain aluminides of transition metals. Combustion synthesis, extrusion, and hot pressing were utilized to obtain dense intermetallics and their composites. Composites were analyzed by X-ray diffraction and microscopy techniques, and tensile properties were measured on button-head and sheet specimens of intermetallics and their composites. Mechanical properties of intermetallics obtained by reaction synthesis and densification compare well with conventionally processed materials. Reaction-synthesis principles were also extended to weld overlays. Possible approaches to obtaining dense products by reaction synthesis and densification are summarized in a schematic illustration.
\end{abstract}

INTERMETALLICS ARE AN ATTRACTIVE CLASS of advanced materials because of their low density, resistance to oxidation, carburization and wear, ordered-crystal structures, and high melting points as compared to many commercially available superalloys. Recent advances in the development and processing of nickel and iron aluminides are described in References 1-4. Aluminides of transition metals possess sufficiently high concentrations of aluminum to form an adherent and fully protective alumina layer on the surface of the material when exposed to air or oxygen atmospheres. The aluminum content of aluminides can range from 10 to $32 \mathrm{wt} \%$ and is significantly greater than that of superalloys based on nickel, iron, and cobalt. The alumina layer formed on the surface of nickel and iron aluminides is primarily responsible for their superior oxidation, carburization, and sulfidation resistance even at temperatures as high as $1100^{\circ} \mathrm{C}$. Therefore, aluminides of transition metals provide oxidation resistance without requiring chromium as an oxide former, and alumina is much more stable than chromia formed on the surfaces of materials.

Although the aluminides' attractive properties have been known for decades, their commercial use has been hampered by lack of understanding of melting and casting techniques for structural intermetallics. The inability to melt intermetallics also prevented the commercial use of intermetallic powders for powder metallurgy applications as well as the development of lightweight intermetallic composites. This paper discusses the application of reaction-synthesis principles in powder processing and in the melting and casting of intermetalitics.

\section{Reaction Synthesis}

The reaction-synthesis technique utilizes the heat of formation of the reaction, to make possible the synthesis of materials with large negative heats of formation with minimum application of external heat. In this technique, a strong exothermic reaction on the upper surface of a powdered compact (such as a mixture of $\mathrm{Ni}$ and $\mathrm{Al}$ ) liberates sufficient heat to raise the temperature of the adjacent layer of reactants so that the reaction becomes self-sustained. This technique is also known as selfpropagating bigh-temperature synthesis, or combustion synthesis, and was extensively investigated in the former Soviet Union (5-8). The reaction-synthesis technique is based primarily on thermodynamic criteria that formation of the products must be accompanied by lowering of Gibbs free energy and release of a significant amount of energy. In general, the formation of intermetallics is an exothermic process (see Table I), producing temperatures in the range of 1000 to $2000^{\circ} \mathrm{C}$ during the reaction.

Heat release and temperature rise due to the exothermic reaction are strongly dependent on the intermetallic's base element and percentage weight of aluminum, and the initial temperature of the components. Thermodynamic principles can be used to calculate the maximum attainable temperatures during the formation of aluminides due to the reaction between nickel or iron and aluminum. Thermophysical properties $(9,10)$ of selected intermetallics and their aluminum content are given in Table II.

The beat released during the formation of an intermetallic compound can be used to carry out an enthalpy balance at a given temperature to determine the maximum attainable temperature and whether the intermetallic would be in liquid or solid state, as in the following emations:

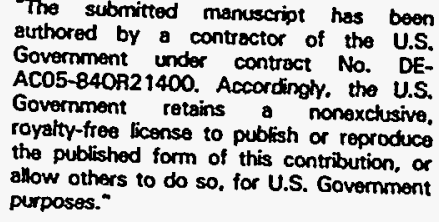
the published form of this contribution, or allow others to do so. for U.S. Government purposes." 


\section{DISCLAIMER}

This report was prepared as an account of work sponsored by an agency of the United States Government. Neither the United States Government nor any agency thereof, nor any of their employees, makes any warranty, express or implied, or assumes any legal liability or responsibility for the accuracy, completeness, or usefulness of any information, apparatus, product, or process disclosed, or represents that its use would not infringe privately owned rights. Reference herein to any specific commercial product, process, or service by trade name, trademark, manufacturer, or otherwise does not necessarily constitute or imply its endorsement, recommendation, or favoring by the United States Government or any agency thereof. The views and opinions of authors expressed herein do not necessarily state or reflect those of the United States Government or any agency thereof. 


\section{DISCLAIMER}

Portions of this document may be illegible in electronic image products. Images are produced from the best available original document. 


$$
\Delta H_{T_{0}}^{r}=\int_{T_{0}}^{T_{\omega_{\alpha}}} C p d T
$$

and

$$
\Delta H_{T_{0}}^{r}=\int_{T_{0}}^{T_{m}} C p d T+f \Delta H_{m} \text {. }
$$

where

$$
\begin{aligned}
\Delta H_{T_{0}}^{r} & =\text { the enthalpy of reaction at } T_{0} \\
C p & =\text { the heat capacities of the product. }
\end{aligned}
$$

Equation 2 above takes into consideration the phase transformation accompanying melting of the product and its latent beat of fusion, $\triangle H_{m}$.

If the product undergoes melting below the adiabatic temperalure, $T_{a d}$, the fraction in molten condition, $f$, can be calculated from Eq. 2. Equations 1 and 2 above assume adiabatic conditions, and $T_{a d}$ in Eq. 1 provides an upper limit for the temperature. A simple calculation of $T_{a d}$, based on Eq. 1, suggests that the maximum temperatures are close to the melting point, and molten product may appear only in the case of NiAl. With an initial temperature of 660 to $800^{\circ} \mathrm{C}$, the enthalpy balance of $\mathrm{Eq} .2$ indicates that the product will be in the liquid state in the case of nickel, iron, and titanium aluminides.

The nature of the reactants and their composition will determine the product formed and also the amount of energy released. Also parameters such as interfacial contact area between nickel and aluminum, aluminum content, and particle size also determine the fraction of the molten product (11-14).

Table I. Heats of formation of selected intermetallics.

\begin{tabular}{|c|c|c|c|}
\hline Intermetallic & $\begin{array}{l}\text { Density } \\
\text { (g/ce) }\end{array}$ & $\begin{array}{l}\text { Weight percent } \\
\text { of aluminum }\end{array}$ & $\begin{array}{c}\text { Melting point } \\
\text { (C) }\end{array}$ \\
\hline $\mathrm{Ni}_{3} \mathrm{Al}$ & 7.293 & 13.28 & 1395 \\
\hline $\begin{array}{l}\mathrm{NiAl} \\
\mathrm{Ni}_{2} \mathrm{Al}_{3}\end{array}$ & $\begin{array}{l}5.91 \\
4.787\end{array}$ & $\begin{array}{l}31.49 \\
40.81\end{array}$ & $\begin{array}{l}1639 \\
1133\end{array}$ \\
\hline $\mathrm{NiAl}_{3}$ & 3.957 & 57.96 & 854 \\
\hline $\mathrm{Fe}_{3} \mathrm{Al}$ & 6.648 & 13.87 & 1502 \\
\hline $\begin{array}{l}\mathrm{FeAl} \\
\mathrm{Fe}_{2} \mathrm{Al}_{5}\end{array}$ & $\begin{array}{l}5.585 \\
3.963\end{array}$ & $\begin{array}{l}32.57 \\
54.70\end{array}$ & $\begin{array}{l}1215 \\
1171\end{array}$ \\
\hline $\mathrm{Ti}_{3} \mathrm{Al}$ & 4.216 & 15.81 & 1600 \\
\hline $\begin{array}{l}\text { TiAl } \\
\mathrm{TiAl}_{3}\end{array}$ & $\begin{array}{l}3.63 \\
3.371\end{array}$ & $\begin{array}{l}36.03 \\
62.82\end{array}$ & $\begin{array}{l}1460 \\
1340\end{array}$ \\
\hline
\end{tabular}

\begin{tabular}{ll}
\hline & $\begin{array}{c}\Delta \mathrm{H}^{\circ} 298 \\
(\mathrm{kcal} / \mathrm{mol})\end{array}$ \\
\hline Intermetallic & -36.0 \\
\hline $\mathrm{NiAl} 3$ & -28.3 \\
$\mathrm{NiAl}$ & -67.5 \\
$\mathrm{Ni} 2 \mathrm{Al} 3$ & -36.6 \\
$\mathrm{Ni3Al}$ & -18.9 \\
$\mathrm{FeAl} 3$ & -12.0 \\
$\mathrm{FeAl}$ & -26.4 \\
$\mathrm{CoAl}$ & -38.5 \\
$\mathrm{CoAl} 4$ & -70.0 \\
$\mathrm{Co} \mathrm{Al}_{5}$ & -23.5 \\
$\mathrm{Ti3Al}$ & -17.4 \\
$\mathrm{TiA}$ & -34.0 \\
$\mathrm{TiAl} 3$ & -27.9 \\
$\mathrm{Ti} 2 \mathrm{Al}_{3}$ & -28.4 \\
$\mathrm{NbAl} 3$ & -19.2 \\
$\mathrm{TaAl}$ & -26.1 \\
$\mathrm{TaAl} 3$ &
\end{tabular}

Table II. Tbermophysical properties and aluminum content $\alpha$ selected intermetallics.

Combustion Wave Propagation in Compacts of Elemental Powders. To illustrate the exothermic diffusiona reactions occurring between nickel and aluminum, compact of nickel and aluminum powders (with average particle size of 1 and $6 \mu \mathrm{m}$, respectively) in the stoichiometric ratios came. sponding to $\mathrm{Ni} 3 \mathrm{Al}$ and $\mathrm{NiAl}$ were pressed to about $40 \%$ porosity. Compacts were ignited in air with an ignition coil os the surface as described in References 15 and 16. The surface heating ignited the compact due to the exothermic reaction between the reactants, and a combustion wave propagated through the compact of $\mathrm{Ni}+\mathrm{Al}$, as shown in Figure 1. A com. bustion wave, in general, preheats the reactants prior to the reaction, and the reaction is generally completed during the passage of the combustion wave, if particle sizes of $\mathrm{Ni}$ and $\mathrm{Al}$ are small. A schematic of combustion wave propagation with preheating and synthesis zones is shown in Figure 2.

During propagation, the combustion wave separates the product which is formed ahead of the reactants from the reax. tants themselves. The wave continues until all the reacants are converted into products and is then extinguished. In a conventional technique, a sample is placed in a fumace and heated for several hours to carry out the reaction at a low heat. ing rate, such as $20^{\circ} \mathrm{C} / \mathrm{min}$. During the heating process, several intermediate compounds form, requiring homogenization. of the product for extended periods of time.

The temperature of the reactants in the combustion zone can be measured by placing a thermocouple (TC) at the centerline of the compact, and the time-temperature profile $\mathrm{can}$ be used to deduce the rate of heating of the reactants and rate of cooling after product formation. TCs placed at the center. line of the compact provided heating and cooling profiles and . maximum temperatures. Heating rates were calculated from the time-temperature profiles obtained during the propagation of combustion waves. The heating rate profile shown in Figure 3 indicates that the reactants were heated to a maximum temperature of at least $1640^{\circ} \mathrm{C}$ at a heating rate of 100,000 $\mathrm{K} / \mathrm{min}$. In contrast, in the case of $3 \mathrm{Ni}+\mathrm{Al}$ compacts, the combustion wave propagated in an unsteady mode, and the 
maximum temperature observed was at least $360^{\circ} \mathrm{C}$ lower than in the case of Ni+Al. X-ray diffraction (XRD) confirmed the formation of $\mathrm{NiAl}$ and $\mathrm{Ni}_{3} \mathrm{Al}$ in the case of $\mathrm{Ni}+\mathrm{Al}$ and $3 \mathrm{Ni}+\mathrm{Al}$

1 mixture. It should be noted that the maximum temperatures observed in the synthesis of $\mathrm{NiAl}$ and $\mathrm{Ni}_{3} \mathrm{Al}$ were above the melting point of $\mathrm{Al}$, and, therefore, aluminide formation can be treated as at least an exothermic diffusional reaction

! between liquid aluminum and solid Ni. Increasing Al particle size lowered the maximum combustion temperature by almost $300^{\circ} \mathrm{C}$ due to the longer time needed to melt the Al during the combustion wave propagation, and X-ray analysis of the combustion-synthesized product indicated several other nickel aluminide phases along with $\mathrm{NiAl}$ (see Figure 4). Although the combustion temperature observed in the synthesis of NiAl was above the melting points of $\mathrm{Al}$ and $\mathrm{Ni}$, the product still had a porosity of at least $30 \%$. Modes of combustion wave propagation and the maximum combustion temperatures are in accordance with the heats of formation, calculated maximum adiabatic combustion temperatures, and published reports (5-8,11-14).

Combustion-synthesized intermetallic compacts were forged during cooling to increase their density. This approach was successful only in the case of NiAl compacts, where forging allowed full densification. Only edge cracks can be seen in the forged compact shown in Figure 5 after about $50 \%$ reduction in thickness. Combustion synthesis also allows incorporation of ceramic reinforcements, and an X-ray diffractogram of combustion-synthesized NiAl with $4 \mathrm{wt} \% \mathrm{Al}_{2} \mathrm{O}_{3}$ is shown in Figure 6. The forged compacts of combustion-synthesized $\mathrm{Ni}_{3} \mathrm{Al}, \mathrm{Fe}_{3} \mathrm{Al}$, and $\mathrm{FeAl}$ showed either porosity or cracks due to the presence of oxide at the particle boundaries and beat losses to the forging dies. Hydrogen annealing and preheating either at 1100 or $1200^{\circ} \mathrm{C}$ in vacuum prior to forging allowed densification of the materials.

Since forging of compacts after the propagation of the combustion wave in $\mathrm{Ni}_{3} \mathrm{Al}, \mathrm{Fe}_{3} \mathrm{Al}$, and $\mathrm{FeAl}$ resulted in cracking, several different metalworking approaches were considered. They included hot rolling of the combustion-synthesized compacts in vacuum-sealed steel covers, hot rolling of elemental powders, and cold rolling of elemental powders into sheets. In some cases, partially mechanically alloyed powders were cold-isostatically pressed (CIP) and reacted in air. The combustion-synthesized compact was hydrogen annealed and hot rolled in steel covers to obtain a sheet for tensile and mechanical properties. Figure 7 shows a sheet of $\mathrm{Fe}_{3} \mathrm{Al}$-based alloy and a (CIP) compact of partially mechanically alloyed powders. Partial mechanical alloying allows partial reaction and cold welding of powders and reduces the volume expansion resulting from the molar volume changes associated with the product-phase formation. CTP compacts were also fully reacted and partially sintered in $\mathrm{H}_{2}$ at a maximum temperature of $1050^{\circ} \mathrm{C}$ for 30 min using a continuous belt furnace at a low belt speed. This approach allowed us to obtain porous materials with minimal distortion and swelling. Porous materials of iron aluminides find applications as coal-gasification filters, and may replace conventional steel filters.

Reactive Hot Extrusion. To obtain bar stock of intermetallics, elemental powders corresponding to $\mathrm{Ni}_{3} \mathrm{Al}$, $\mathrm{NiAl}$, and $\mathrm{Fe}_{3} \mathrm{Al}$ were packed in aluminum containers of $5.04 \mathrm{~cm}$ diam and were evacuated by heating the cans at $150^{\circ} \mathrm{C}$ for at least $6 \mathrm{~h}$. Sealed cans were heated prior to extrusion, and extrusion of elemental powders with reduction ratios of 1:20,1:16, and 1:12 initiated exothermic diffusional reactions between $\mathrm{Al}$ and $\mathrm{Ni}$, and $\mathrm{Al}$ and Fe powders. The frictional heating associated with the extrusion allowed melting of aluminum, which in turn triggered the exothermic reaction. The heat generated by the reaction melted the alu. minum can and also oxidized the aluminum and the product (17). Figure 8 is a photograph of the product obtained after extrusion of aluminum can with $\mathrm{Fe}_{3} \mathrm{Al}$.

Recently, powdered mixtures in steel cans were extruded at $1200^{\circ} \mathrm{C}$ with a reduction ratio of $16: 1$ by ensuring that the reaction was complete prior to extrusion inside a steel can. The microstructure of $\mathrm{Ni}_{3} \mathrm{Al}$ extruded with 4 wt $\% \mathrm{ZrO}_{2}$ is shown in Figure 9. The extrusion ratio allowed full densification, and the mechanical properties of the composite compare well with the published reports on composites (18).

Simultaneous Reaction Synthesis and Densification. Powders corresponding to nickel and iron aluminides with ceramic reinforcements were successfully hot pressed by following the densification with the help of ram travel and application of pressure at the melting point of aluminum. A signiflcant compaction occurred close to the melting point of aluminum, and an upward movement was observed coinciding with the formation of aluminides. The upward movement is attributed to the volume expansion associated with the molar volume change of nickel and iron to their respective aluminides. Table III compares mechanical properties of intermetallics obtained in as-pressed condition using button-head specimens at a strain rate of $4.572 \mathrm{~mm} / \mathrm{min}$ with the published data. The results show excellent agreement with the published reports on cast $\mathrm{Ni}_{3} \mathrm{Al}$ and hot-isostatically pressed materials. The microhardnesses of several hot-pressed intermetallics are shown in Figure 10.

Hot-pressed intermetallics and their composites were also processed into sheet specimens, and tensile specimens were cut from the sheets. Yield strengths, ultimate tensile strengths, and elongations of $\mathrm{Fe}-24 \mathrm{Al}$ (Fe-240) with $\mathrm{B}$ of $0.005, \mathrm{Zr}$ of $0.2, C$ of 0.06 , and Mo of 0.42 wt \% are shown in Figure 11 and are compared with $\mathrm{FeAl}$ alloys containing alumina additions.

Weld Overlays. Reaction-synthesis principles were also extended to obtain weld overlays of nickel aluminides. Nickel powder was placed in an aluminum foil and was swaged into a weld rod prior to placing a weld overlay on top of steel. The XRD pattern of the weld overlay clearly indicates the formation of nickel aluminides (see Figure 12). Figure 13 shows the hardnesses of the weld overlay and base metal.

\section{Application of Reaction-Synthesis Principles in Melting and Casting of Intermetallics}

Melting of intermetallics, unlike melting conventional steels, alloys, and superalloys, requires consideration of the following factors: (1) the differences between the melting points of aluminum and transition metals such as nickel, iron, titanium, and niobium; (2) the large amounts of aluminum (10 to $30 \mathrm{wt} \%$ ) as opposed to < $0.5 \% \mathrm{Al}$ in most commercial alloys and $<5$ wt \% Al in superalloys; (3) the exothermic nature of the intermetallic compound formation (see Table 1); 
(4) the higher melting points of some intermetallics than those of aluminum and transition metals; and (5) reactivity and vapor pressures of alloying elements in atmospheres such as air and vacuum at the melt temperatures.

Along with the above, melting techniques and process conditions must also be taken into consideration prior to determining whether a particular melting technique is suitable and economical for the melting of intermetallics. Important process parameters are crucible type; melting atmosphere (air, inert gas, vacuum); furnace loading of low- and high-meltingpoint metals; control of impurities such as carbon, nitrogen, sulfur, etc.; and most important, the ability to use recycled material with close control of target composition.

Since formation of aluminides of transition metals is accompanied by a significant heat release, conventional melting processes need to be modified to effectively utilize the exothermic reactions. Proper utilization of the exothermic reaction can result in substantial energy savings and may also reduce the time needed for melting. The proper use of the heat released can also result in control of the chemical composition and formation of oxidation product (slag). The lack of understanding of heat released between the alloying elements can have serious implications in the melting of aluminides, and this lack of knowledge has prevented commercial exploitation of intermetallic properties by the industry.

Conventional Melting Practice. In a conventional melting process, nickel aluminide is obtained by melting nickel initially, and aluminum is then loaded into the molten nickel melt stock. This practice requires heating the melt stock to a temperature of $1600^{\circ} \mathrm{C}$ prior to the addition of aluminum since melting of aluminum is generally not preferred. The addition of aluminum to a molten nickel melt stock at $1600^{\circ} \mathrm{C}$ initiates an instantaneous, violent, exothermic reaction. A peak temperature of $2300^{\circ} \mathrm{C}$ is seen within $1 \mathrm{~min}$. The crucible was at a temperature of $2100^{\circ} \mathrm{C}$ for several minutes and a high-temperature vapor cloud escapes from the crucible due to the oxidation of aluminum.

Therefore, the addition of aluminum to the melt stock is not desirable due to the possibility of exceeding the safe operating temperatures of crucibles, but also because an uncontrolled oxidation could raise the temperature of the crucible much higher. Also, the addition of aluminum to a molten nickel melt stock could potentially lead to disastrous results if molten metal comes in contact with water due to cracking of the crucible.

Exo-Melt ${ }^{\mathrm{M}}$ Process. We addressed the above safety issues, and melting and casting of over 100 heats of Ni3Aland Fe3Al-based alloys was accomplished successfully with the Exo-Melt ${ }^{\text {TM }}$ process to obtain several thousand pounds of nickel and iron aluminides. The Exo-Melt ${ }^{\text {TM }}$ process consists of dividing the melt stock into several parts in a furnace-loading sequence such that a mostly exothermic reaction with a high-adiabatic combustion temperature is favored initially, leading to a molten product (see ref. 4 for a schematic of furnace loading). In the case of nickel aluminides, the formation of NiAl is highly exothermic and the adiabatic combustion temperature is the melting point of NiAl. On the other hand, $\mathrm{Ni}$ Al formation would only give rise to a combustion temperature of $1300^{\circ} \mathrm{C}$, and a value of $=1400^{\circ} \mathrm{C}$ (melting point of $\mathrm{Ni} 3 \mathrm{Al} \approx 1395^{\circ} \mathrm{C}$ ) can be achieved if the melt stock is preheated to the melting point of aluminum.
In the Exo-Melt ${ }^{\text {nI }}$ process, nickel was split into two First, the top part of the loading was combined with at aluminum to initially form NiAl. Second, the remain the nickel of the melt stock was loaded at the bottom. All in alloying elements of a particular melt stock were loase between the top and bottom layers of nickel. Melting carried out in air under an argon gas cover by monitoriog the temperatures of the melt stock. Temperature measures the and a video recording of melting confirmed the occurrences exothermic reaction in the top layer. Thermodynamic alo lations suggest that the reaction of molten aluminum with the nickel melt stock at a temperature of $700^{\circ} \mathrm{C}$ or above leads molten NiAl. Alloying elements are dissolved as the mollo $\mathrm{NiAl}$ drips down onto the heated nickel melt stock. Additional NiAl liquid is formed as the furnace temperature is mised, and the exothermic reaction continues until the reaction betwe molten aluminum and heated nickel melt stock is complete. The crucible temperature never exceeded the melting point $\alpha$ NiAl. The crucible life is extended since the crucible experj. ences a maximum temperature of $1640^{\circ} \mathrm{C}$ for about $10 \mathrm{~min}$ a most.

Target composition of an alloy can be reached much more easily and safely with the Exo-Melt ${ }^{\text {Tu }}$ process than with conventional process. In addition, the Exo-Melt process allows $47 \%$ energy savings over conventional melting prac tices (19). The process principles are applicable even for 3000-1b melt stock, and the process was used to melt and cay at least $16,000 \mathrm{lb}$ of nickel aluminides based on $\mathrm{Ni}_{3} \mathrm{Al}$. This technique has recently been extended to the melting of iroo and titanium aluminides. The low levels of oxygen and nitro. gen ( $<40 \mathrm{ppm}$ by weight) indicate that the $\mathrm{Al}_{2} \mathrm{O}_{3}$ (slag) film formed on top of the molten alloy is highly impervious. Melting of the alloys under an argon gas cover in air reduced the oxygen, nitrogen, and hydrogen levels, and enhanced the recovery of elements.

\section{Summary and Conclusions}

The exothermic reaction associated with the formation of aluminides of nickel, iron, and titanium was successfully utilized to obtain porous and dense intermetallics and their com. posites. Fully dense intermetallics and their composites were obtained by (a) forging, (b) forging and rolling, (c) hot extrusion, and (d) by application of pressure. The Exo-Melt ${ }^{\mathrm{T}}$ process was developed by extending reaction-synthesis principles to the melting and casting of intermetallics. Reaction. synthesis principles can be used in a number of ways and Figure 14 is a schematic showing some of the possible approaches to implementing reaction-synthesis principles.

\section{Acknowledgements}

This research was conducted by S. C. Deevi, who is on sabbatical under the Philip Morris Continuing Educational Fellowship Program. The authors thank E. C. Hatrield and K. S. Blakeley for experimental work, E. K. Ohriner and C. Blue for paper review, Erica Alkin for manuscript preparation, and Kathy Spence for editing.

Research was sponsored by the U.S. Department of Energy, Assistant Secretary for Energy Efficiency and 
Renewabls Energy, Office of Industrial Technologies, Kdranced Industrial Materials Program, under contract DE$+$

1. Sikka, V.K., in Physical Metallurgy and Processing of Intermetallic Compounds, N.S. Stoloff and V.K. Sikka, eds., Chapman \& Hall, New York, New York (1995)

2 McKamey, C.B., J. H. DeVan, P. F. Tortorelli, and V.K. Sikka, J. Mat. Res. 6(8), 1779-1805 (1991)

3. Koch, C.C., C. T. Liu, and N. S. Stoloff, eds., High Temperature Ordered Intermetallic Alloys, Proceedings of Materials Research Society Symposium (Mater. Res. Soc. Symp. Proc. 39, Pittsburgh, Pennsylvania (1985)

4. See paper by V.K. Sikka and S.C. Deevi, "Intermetallics for Structural Applications" in these proceedings

5. Frankhouser, W.., K. W. Brendley, M. C. Kieszek and S. T. Sullivan, Gasless Combustion Synthesis of Refractory Compounds, Noyes Publications, Park Ridge, New Jersey, 10 (1985)

6. Munir, Z.A., and V. Anselmi-Tamburini, Mater Sci. Rep. 3, 277-365 (1989)

7. Naiborodenko, Y.S., and V.I. Itin, Combust Explos. Shock Waves 11, 293-300 (1975)

8. Naiborodenko, Y.S., and V.I. Itin, Combust. Explos. Shock Waves 11, 626-29 (1975)
9. Hultgren, R. L., et al., Selected Values of the Thermodynamic Properties of Binary Alloys, American Society for Metals, Metals Park, Ohio (1973)

10. Kubaschewski, O., and C.B. Alcock, Metallurgical Thermochemistr, 5th Edition, Pergamon Press, New York (1979)

11. German, R. M., in Thermal Analysis in Metallurgy, R.D. Shull and A. Joshi, eds., 205-31, The Minerals, Metals \& Materials Society, Warrendale, Pennsylvania (1992)

12. Philpot, K.A., Z.A. Munir, and J.B. Holt, J. Mater. Sci. $22,159-69$ (1987)

13. V.I., A.D. Bratchikov, and L.N. Postnikova, Sov.Powder Metall Met.Ceram. 19, 315-18 (1980)

14. Bose, A., B.H. Rabin, and R.M. German, Powder Metall Int. 20(3), 25-30 (1988)

15. Deevi, S.C., J. Mater. Sci, 26, 2662 (1991)

16. Deevi, S.C., J. Mater. Sci., 26, 3343 (1991)

17. Deevi, S.C., and V.K. Sikka, in Proceedings of Materials Research Society Symposium, Mater. Res, Soc. Symp. Proc. 364, Piusburgh, Pennsylvania (1995)

18. German, R.M., and R.G. Iacocca, "Powder Metallurgy Processing of Intermetallics" in Physical Metallurgy and Processing of Intermetallic Compounds, N.S. Stoloff and V.K. Sikka, eds., Chapman \& Hall, New York, New York, 1995

19. Sikka, V.K., S.C. Deevi, and J.D. Vought, to be published in Adv. Mater. Process. (1995)

Table III. Tensile properties of intermetallic powders consolidated using a hot press.

\begin{tabular}{|c|c|c|c|c|}
\hline Sample & $\begin{array}{l}\text { Test } \\
\text { temperature } \\
\left({ }^{\circ} \mathrm{C}\right)\end{array}$ & $\begin{array}{l}\text { Yield } \\
\text { strength } \\
\text { (MPa) }\end{array}$ & $\begin{array}{l}\text { Tensile } \\
\text { strength } \\
\text { (MPa) }\end{array}$ & $\begin{array}{l}\text { Total } \\
\text { elongation } \\
(\%)\end{array}$ \\
\hline $\begin{array}{l}\mathrm{IC}-50^{a} \\
(\mathrm{Ni} 3 \mathrm{Al}+\mathrm{B})\end{array}$ & 23 & 401 & 401 & 0.33 \\
\hline IC- $50+2$ wt. $\% \mathrm{Al}_{2} \mathrm{O}_{3}{ }^{a}$ & 23 & 521 & 625 & 4.74 \\
\hline $\mathrm{IC}-50+4 \mathrm{wt} . \% \mathrm{Al}_{2} \mathrm{O}_{3}{ }^{a}$ & 23 & 486 & 486 & 0.93 \\
\hline $\begin{array}{l}\mathrm{Ni} 3 \mathrm{Al}+\mathrm{B}^{b} \\
\left(\text { As HIP }, 800^{\circ} \mathrm{C}\right)\end{array}$ & 25 & 286 & - & 14.8 \\
\hline $\begin{array}{l}\mathrm{Ni} 3 \mathrm{Al}+\mathrm{B}^{b} \\
\left(\mathrm{As} \mathrm{HIP}, 1100^{\circ} \mathrm{C}\right)\end{array}$ & 25 & 494 & - & 2.1 \\
\hline $\begin{array}{l}\mathrm{Ni} 3 \mathrm{Al}+\mathrm{B}^{b} \\
\text { (Heat treat, } 1100^{\circ} \mathrm{C} \text { HIPC) }\end{array}$ & 25 & 591 & - & 5.2 \\
\hline $\begin{array}{l}\mathrm{Ni} 3 \mathrm{Al}+3 \text { vol } \% \mathrm{Al}_{2} \mathrm{O}_{3} \text { fiber } \\
\text { (As HIPC, } 800^{\circ} \mathrm{C} \text { ) }\end{array}$ & 25 & 474 & - & 1.0 \\
\hline
\end{tabular}

astrain rate $=4.572 \mathrm{~mm} / \mathrm{min}$

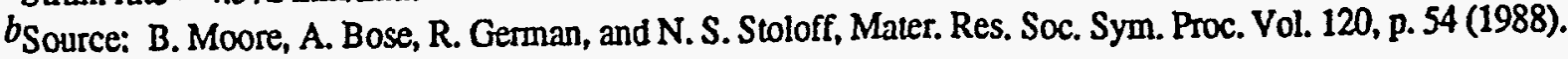

CHIP $=$ hot-isostatically pressed. 


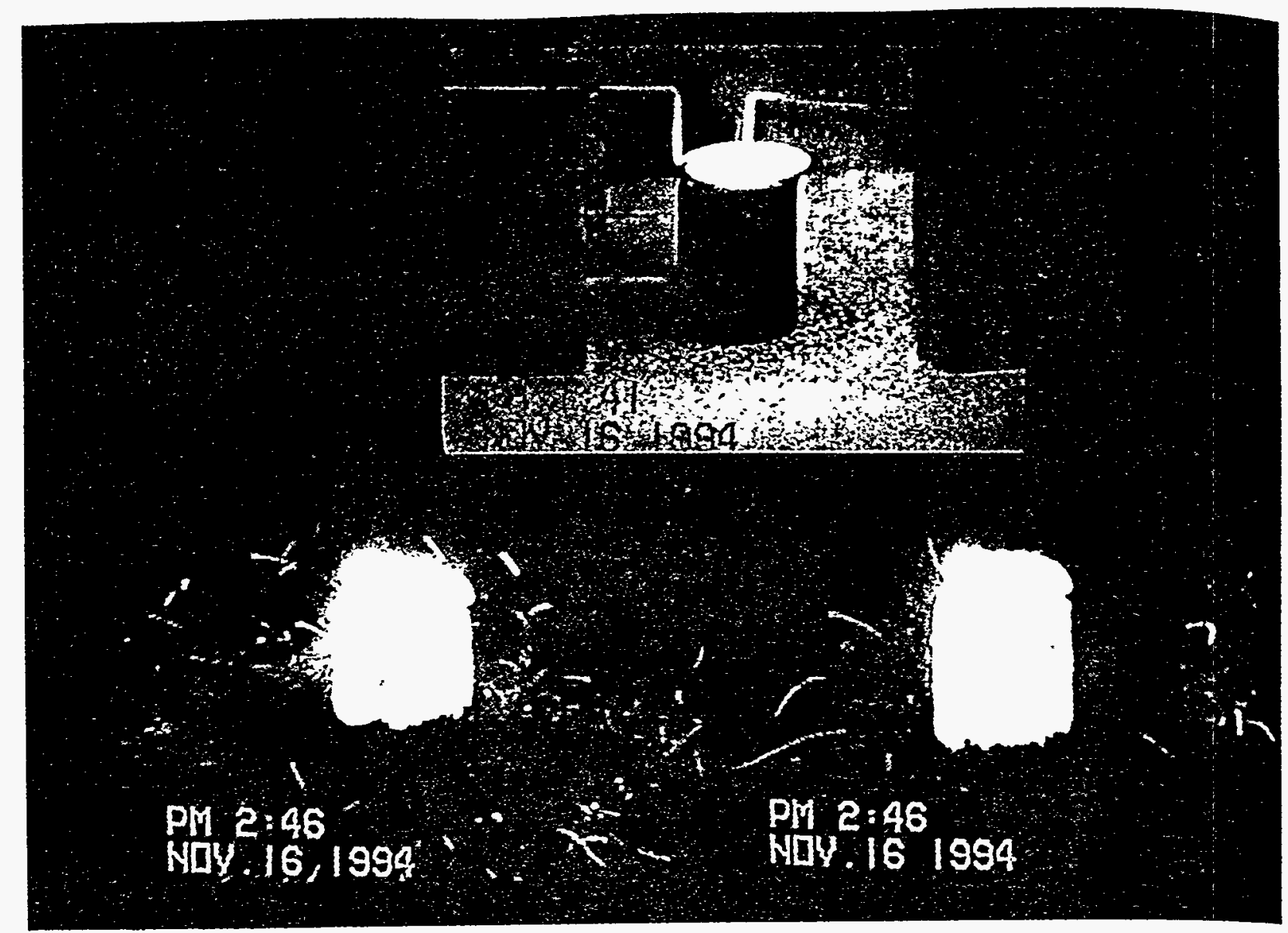

Fig. 1 - Combustion wave propagation in a compact of Ni+Al mixture.

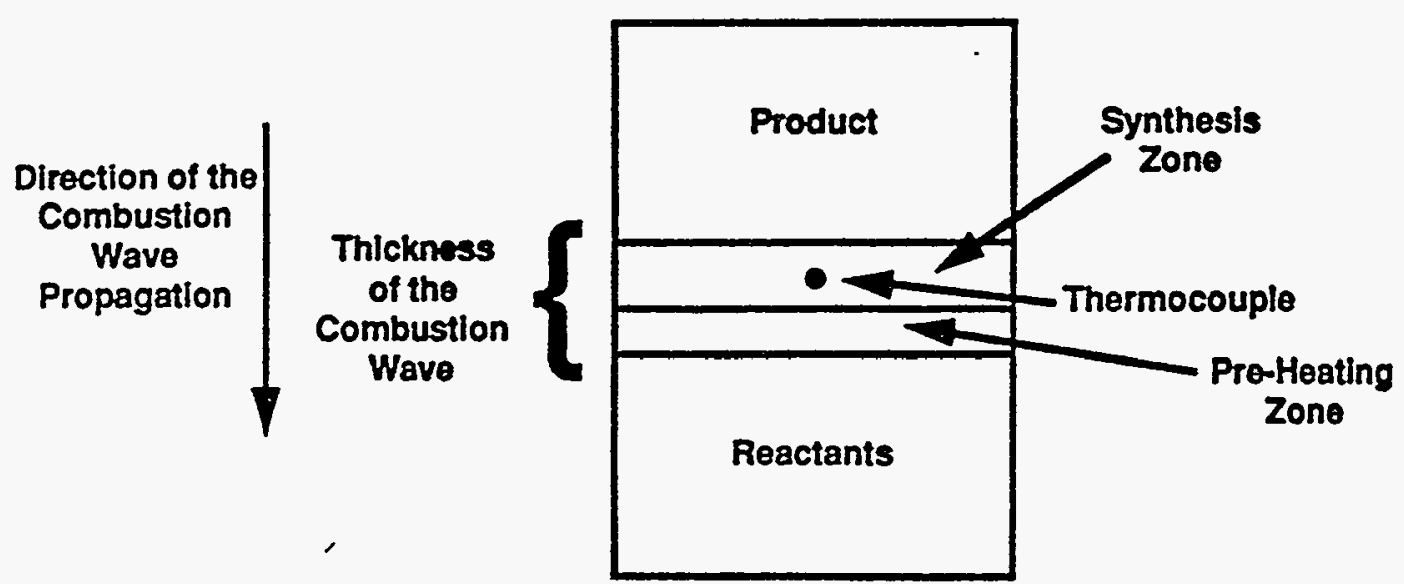

Fig. 2- Schematic of the combustion wave propagation in powdered mixtures. 


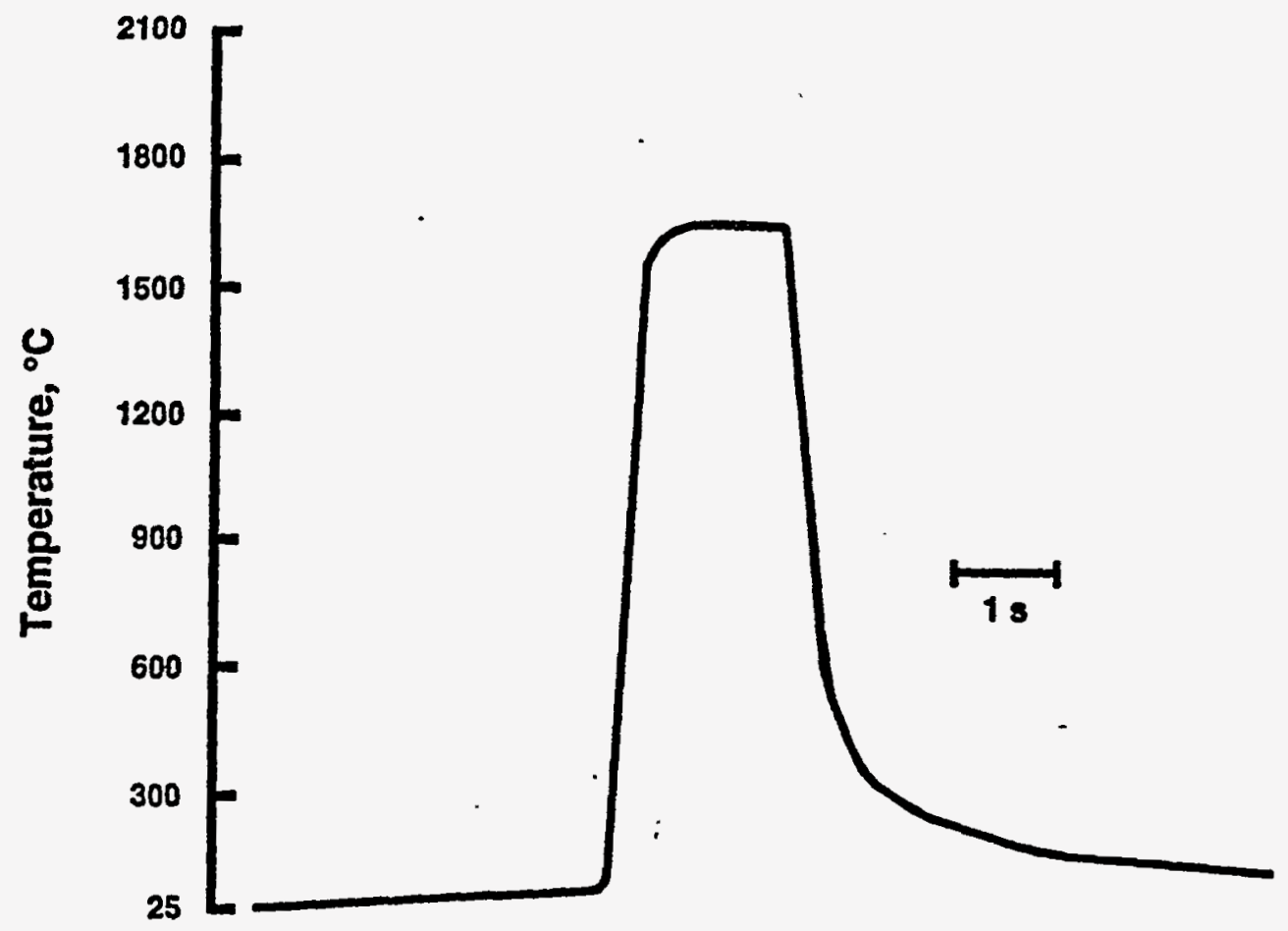

Fig. 3 - Time-temperature profile obtained during the propagation of a combustion wave.
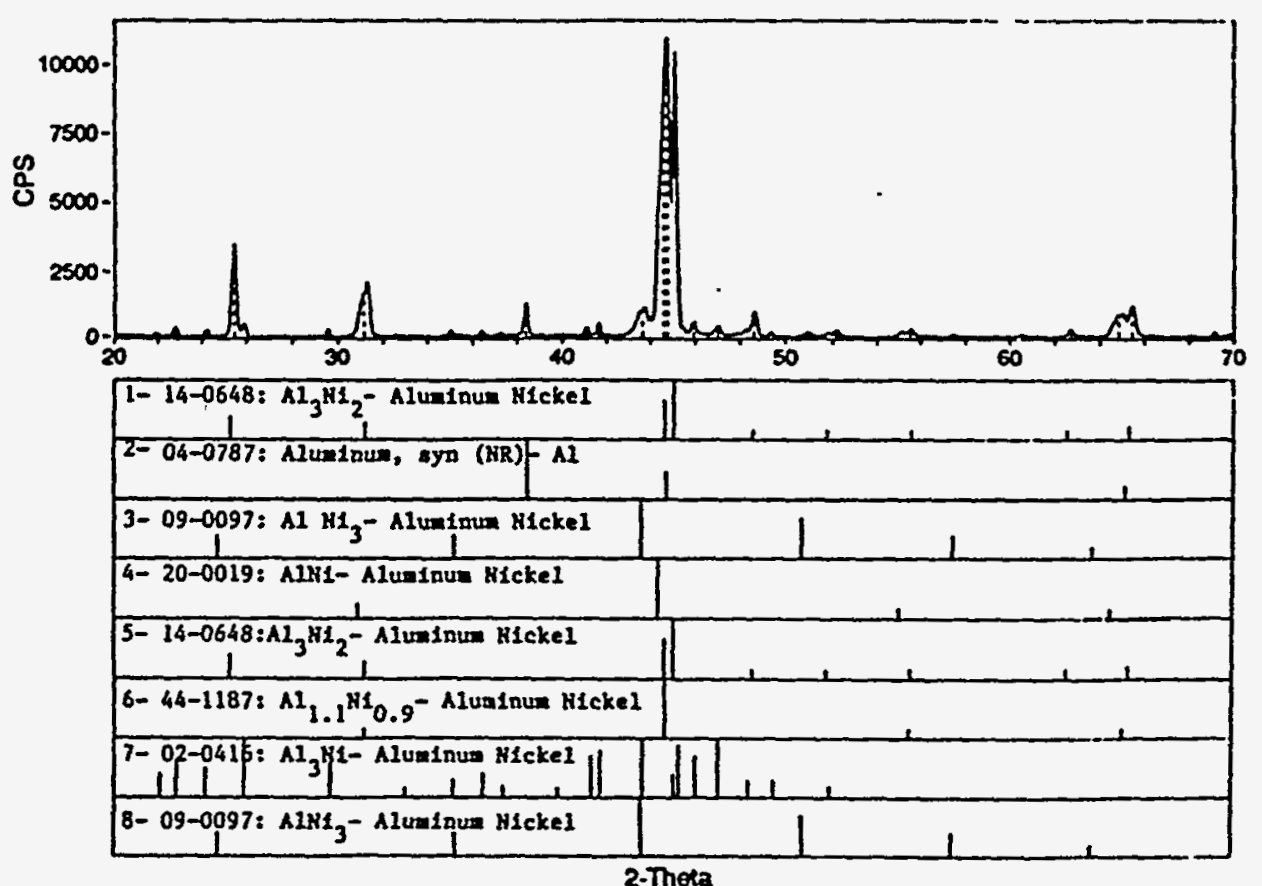

Fig. 4-X-ray diffraction pattern of a combustion-synthesized NitAl mixture containing

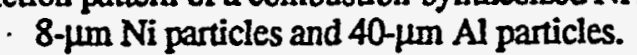




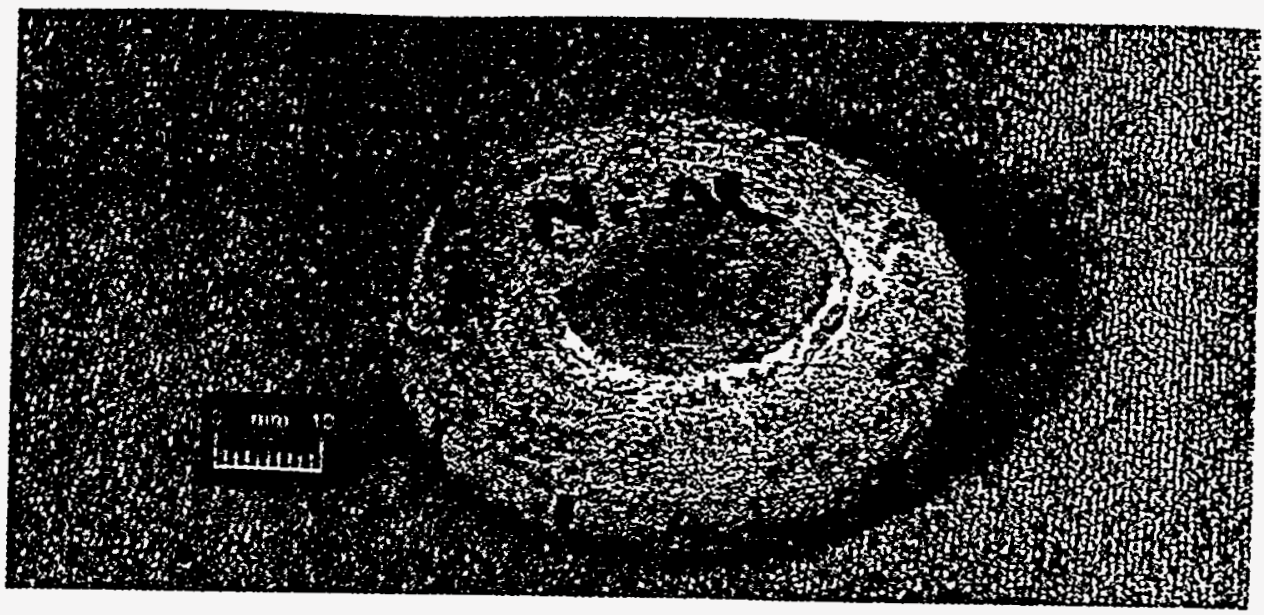

Fig. 5-Forged compact of combustion-synthesized NiAl after $50 \%$ reduction. Forging was done during the cooldown period after the passage of the combustion wave.

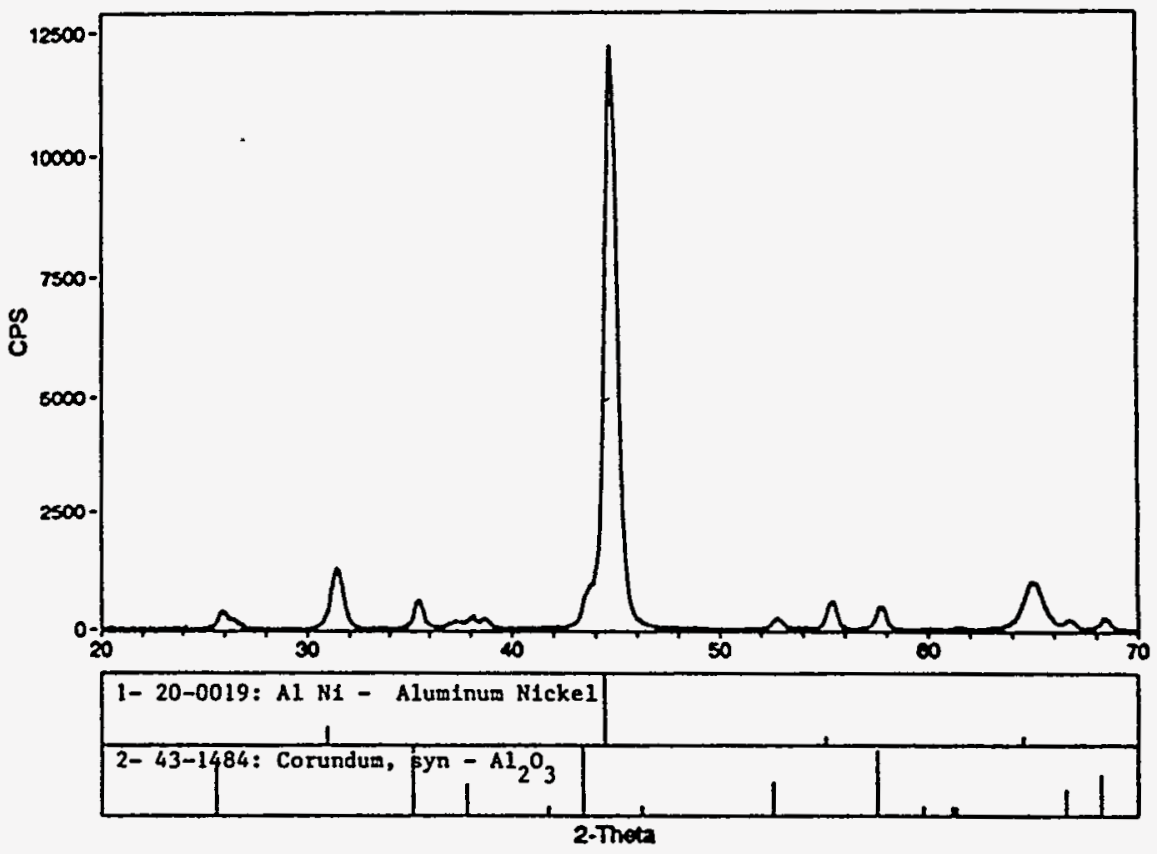

Fig. 6-X-ray diffraction pattern of combustion-synthesized NiAl with 4 wt \% $\mathrm{Al}_{2} \mathrm{O}_{3}$.

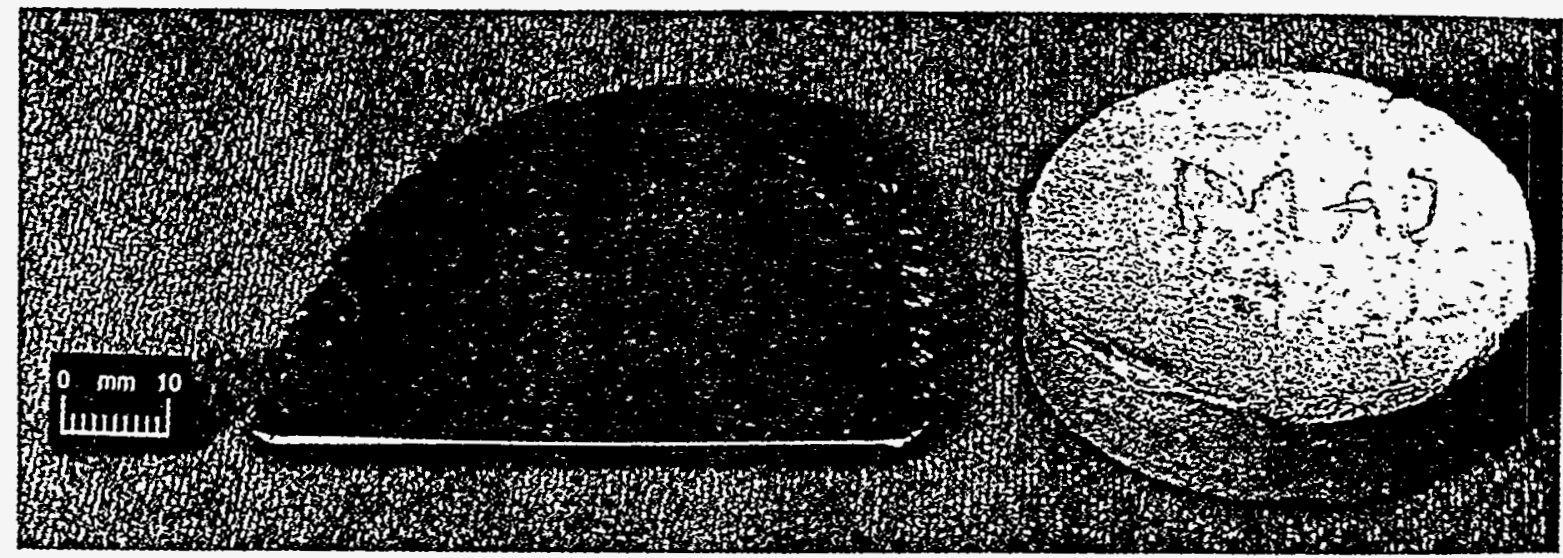

Fig. 7 - Sheet of Fe3Al-based alloy obtained after rolling of combustion-synthesized Fe3Al. 


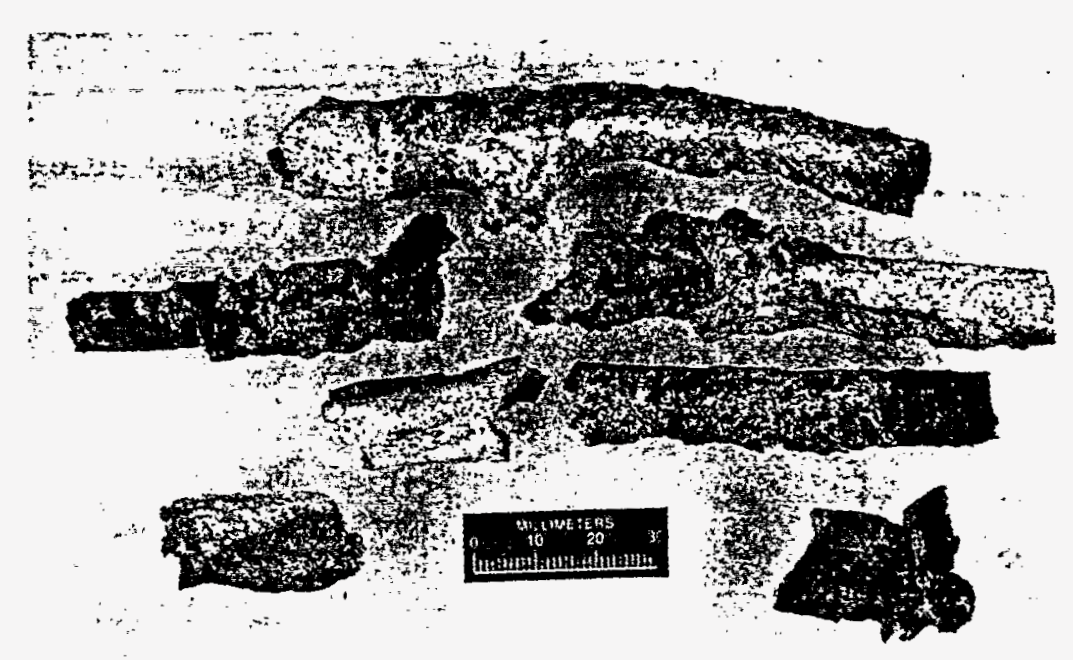

Fig. 8- Extruded rod of $\mathrm{Fe}_{3} \mathrm{Al}$ after extrusion of $3 \mathrm{Fe}+\mathrm{Al}$ mixture at $425^{\circ} \mathrm{C}$ in an aluminum can.

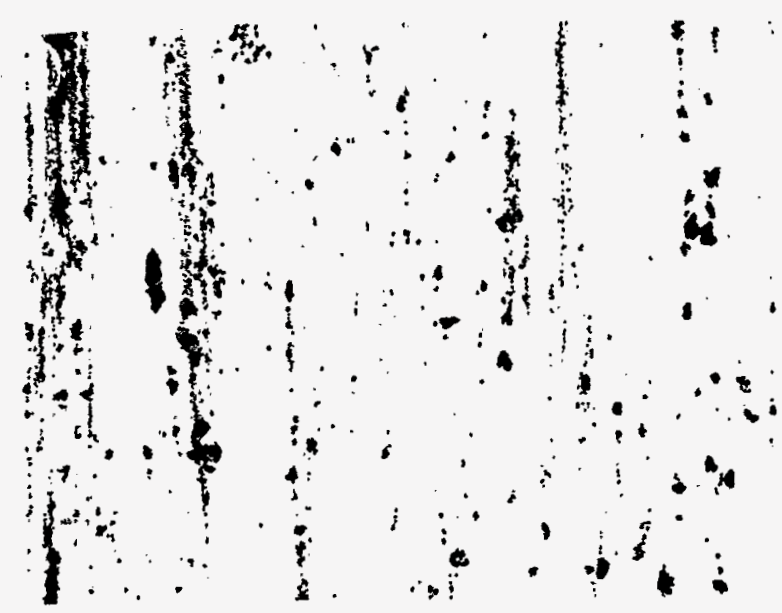

(a)

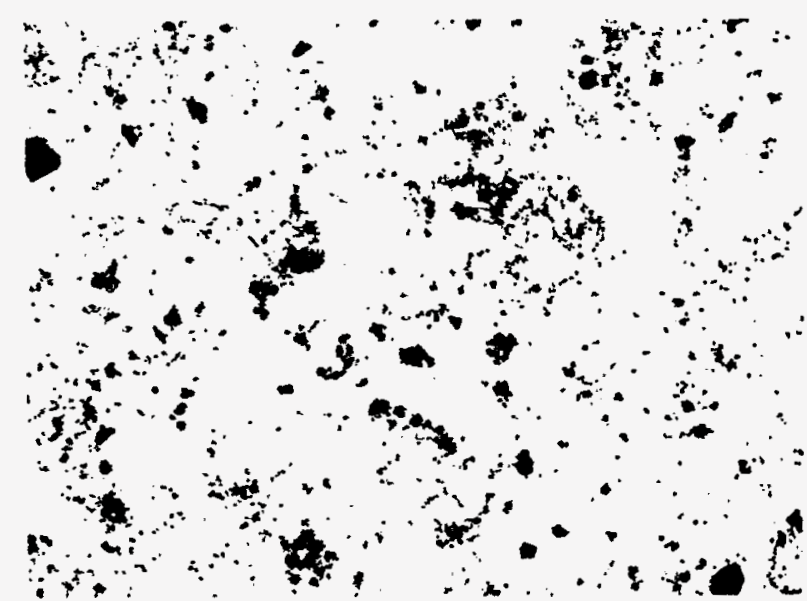

(b)

Fig. 9 - Microstructure of $\mathrm{Ni}_{3} \mathrm{Al}$ with $4 \mathrm{wt} \% \mathrm{ZrO}_{2}$ obtained by hot extrusion of $\mathrm{Ni}, \mathrm{Al}, \mathrm{B}, \mathrm{Zr}$, and $4 \mathrm{wt} \% \mathrm{ZrO}_{2}$. (a) Longitudinal section; (b) transverse section. Both $200 \times$ magnification.

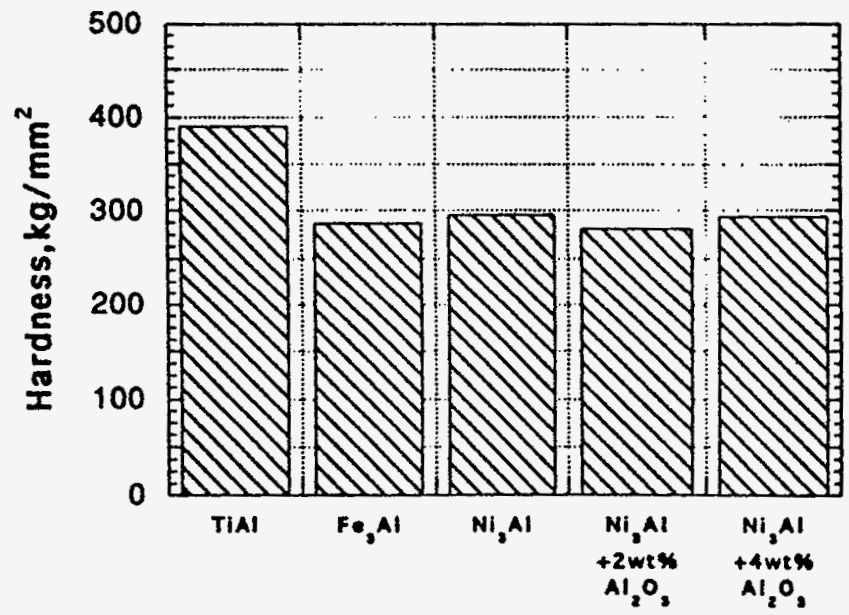

Fig. 10 - Vickers microhardnesses of intermetallics hot pressed from their elemental powders. 
(a)

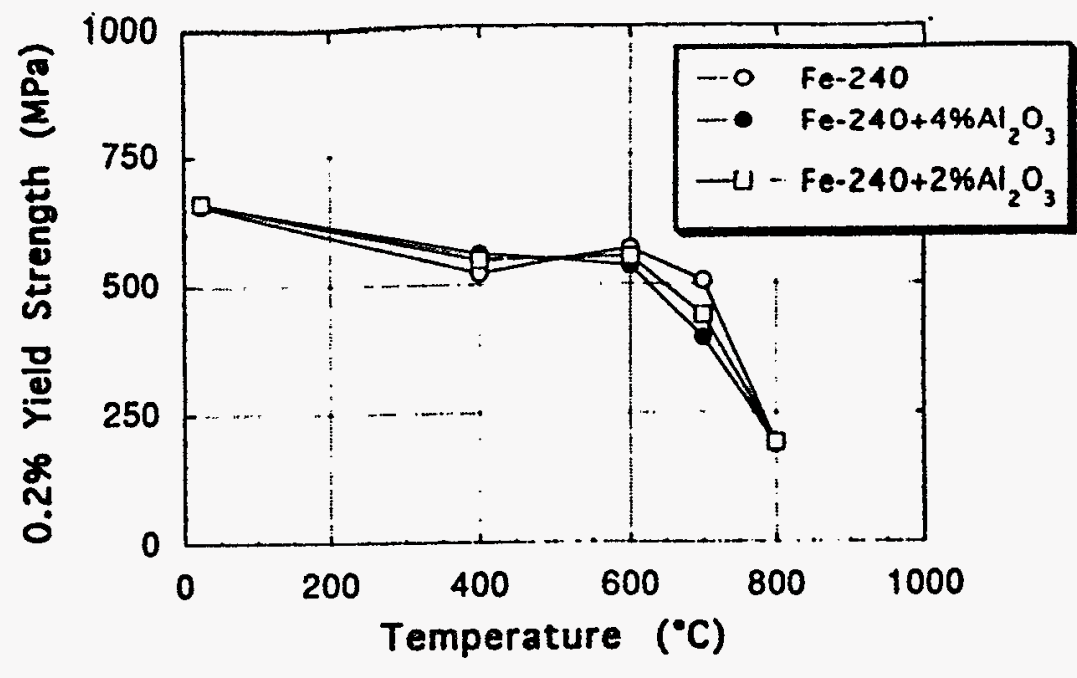

(b)

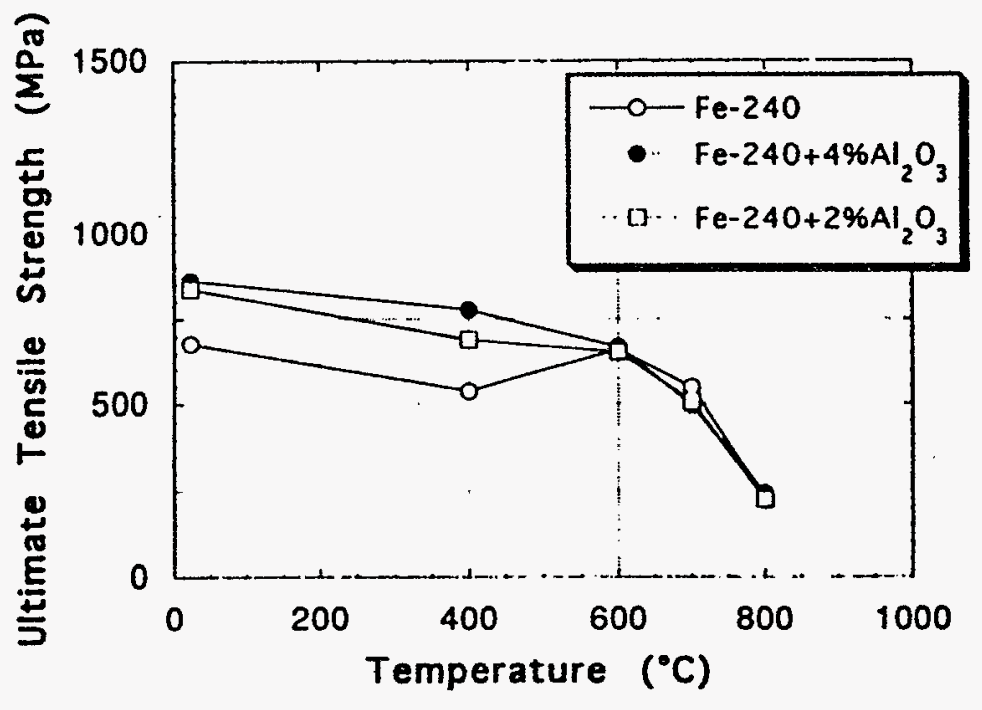

(c)

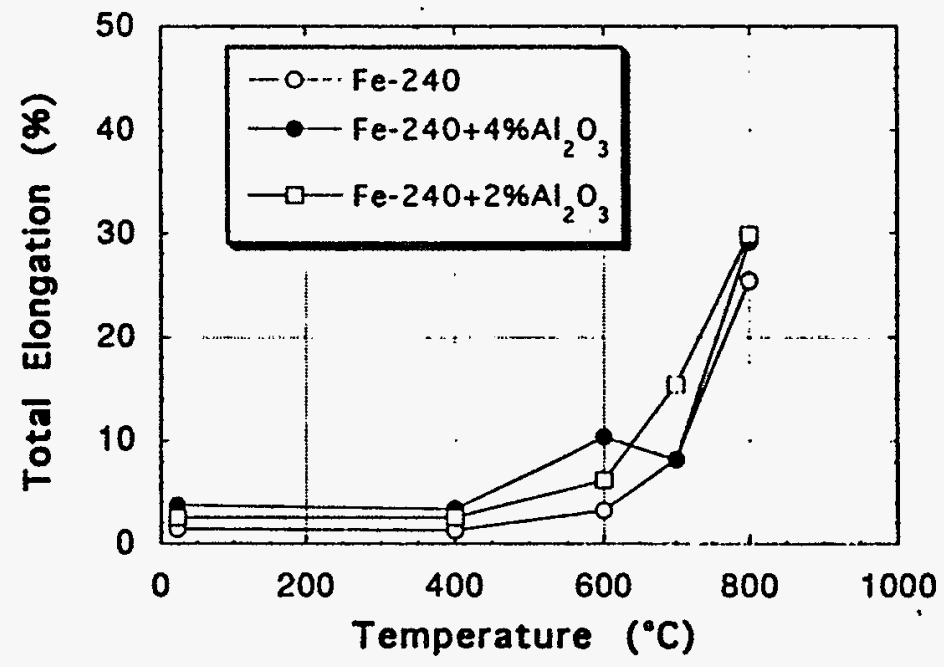

Fig. 11 - (a) Yield strengths, (b) ultimate tensile strengths, and (c) tensile elongations of $\mathrm{Fe}-24 \mathrm{wt} \% \mathrm{Al}$ alloy with alumina additions. 


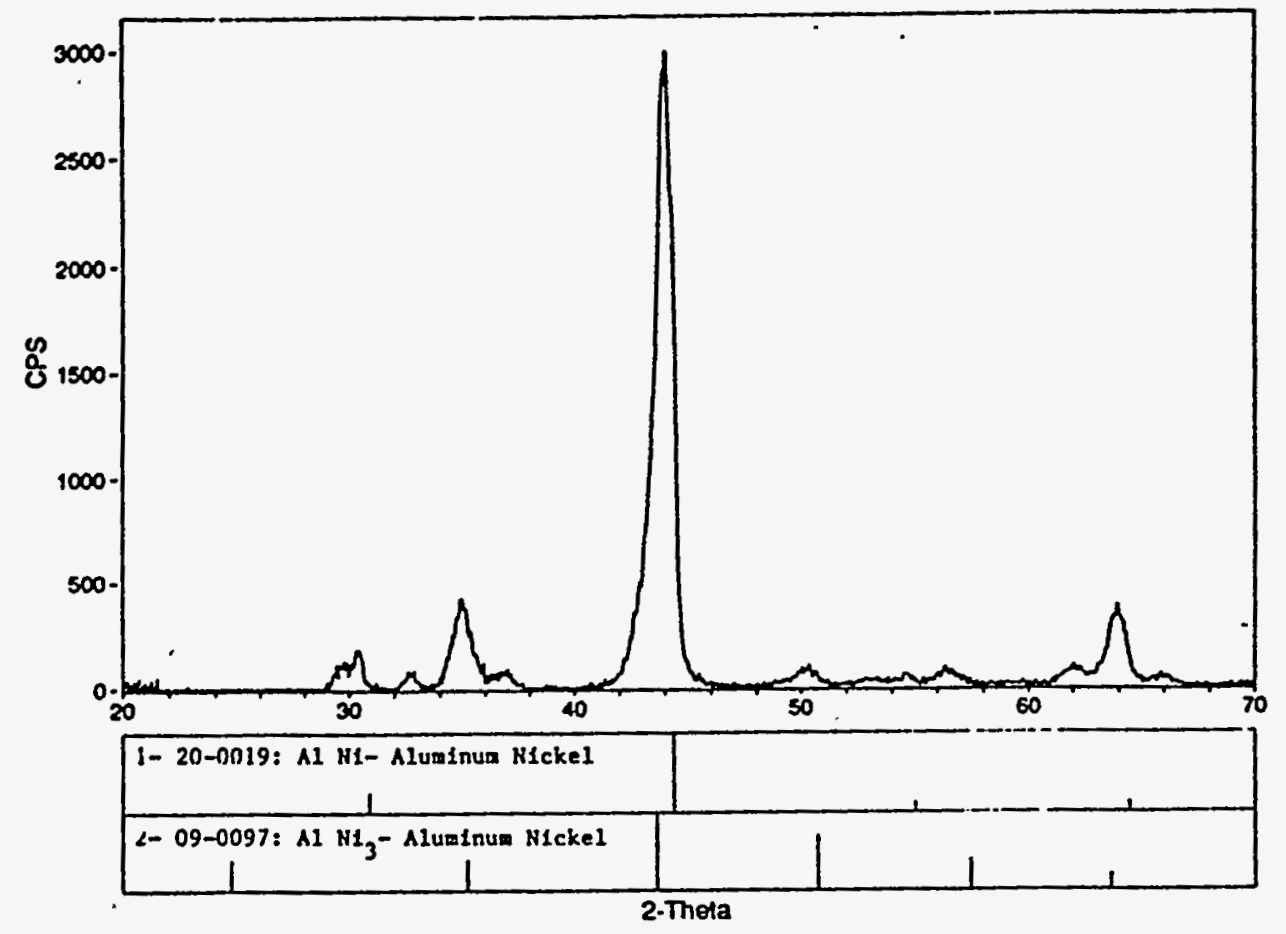

Fig. 12 - X-ray diffraction pattern of a nickel aluminide weld layer obtained from swaged Al foil containing nickel powder.

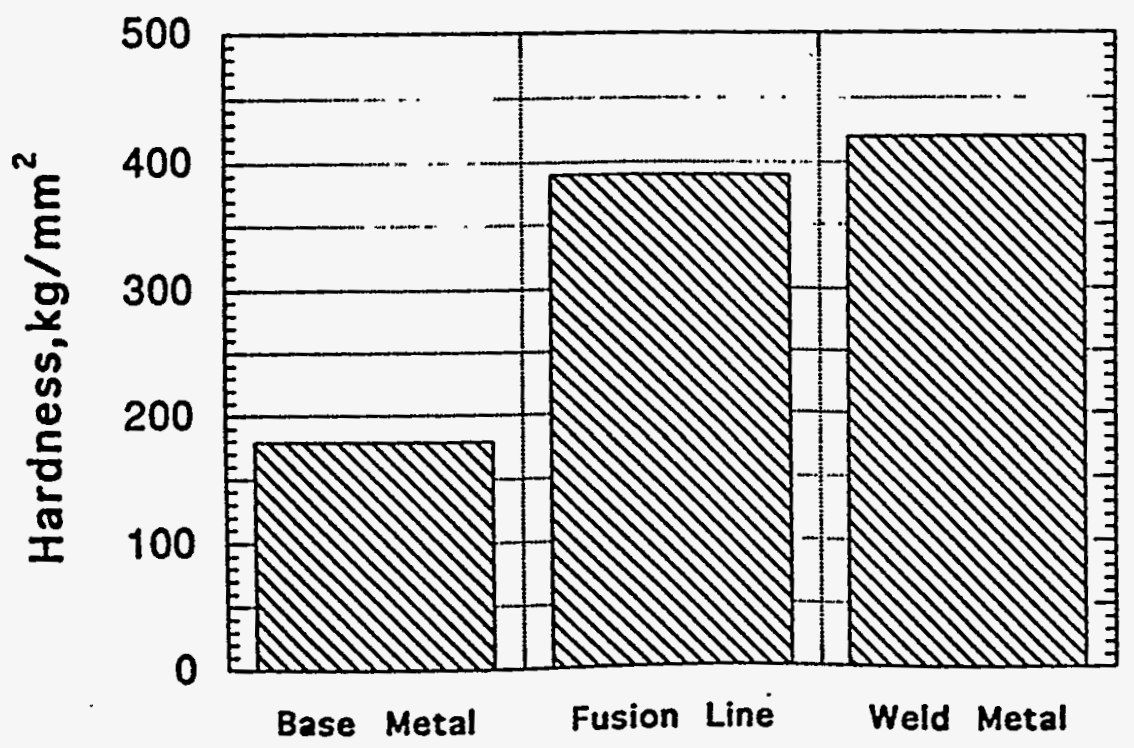

Fig. 13 - A comparison of hardnesses of base metal and weld overlay on stainless steel. 


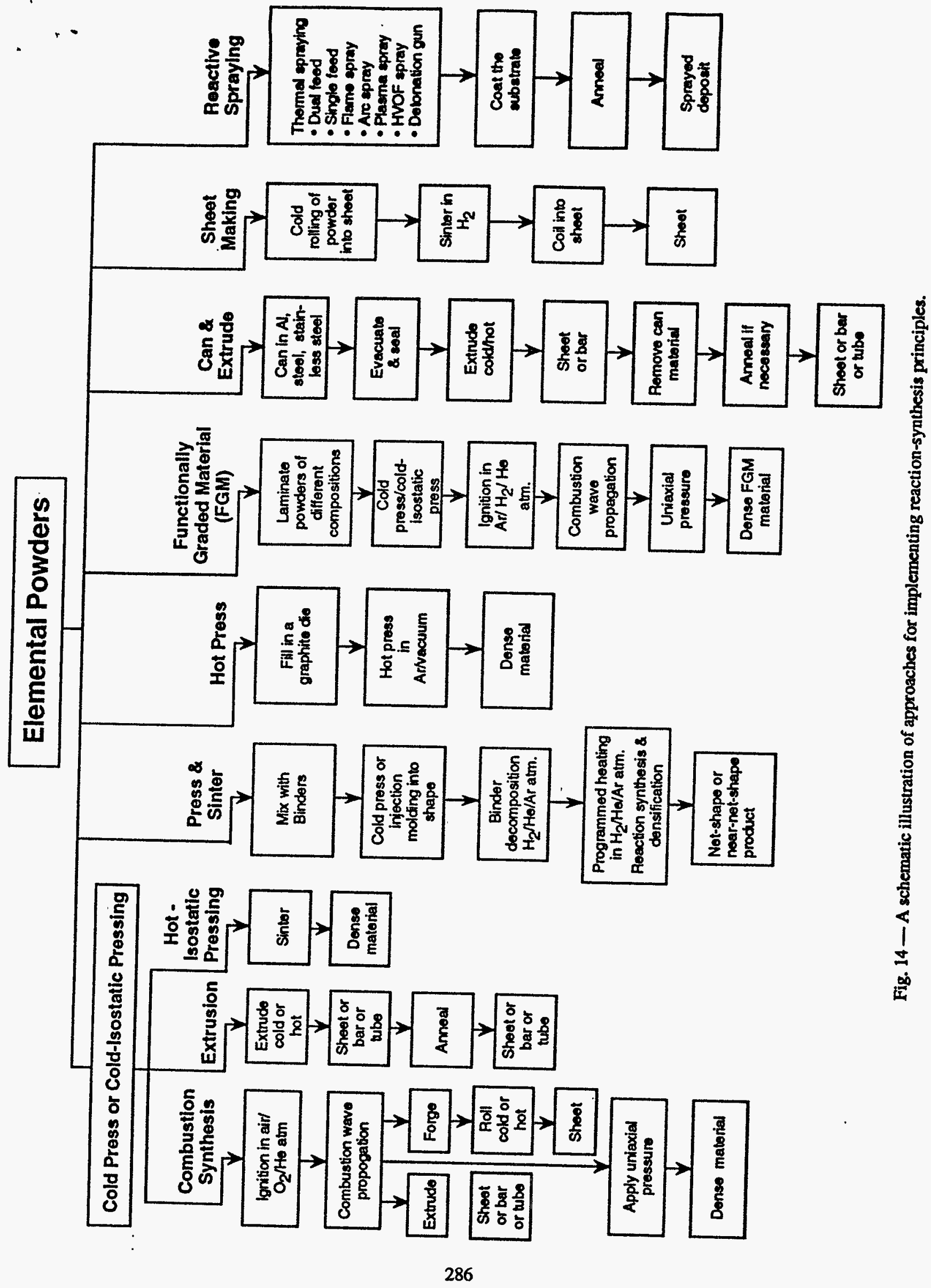

